
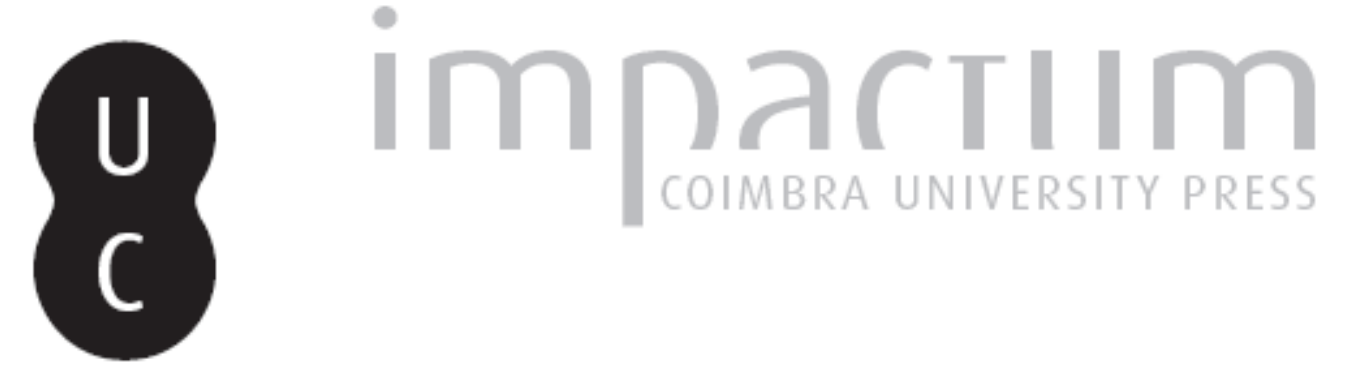

A comemoração do centenário da Revolução Francesa na imprensa diária portuense

Autor(es): $\quad$ Costa, Isilda Braga da; Moura, José Paulo; Mota, Salvador Magalhães

Publicado por: Imprensa da Universidade de Coimbra

URL persistente:

URI:http://hdl.handle.net/10316.2/43792

DOI:

DOI:https://doi.org/10.14195/2183-8925_10_33

Accessed : $\quad$ 26-Apr-2023 15:31:24

A navegação consulta e descarregamento dos títulos inseridos nas Bibliotecas Digitais UC Digitalis, UC Pombalina e UC Impactum, pressupõem a aceitação plena e sem reservas dos Termos e Condições de Uso destas Bibliotecas Digitais, disponíveis em https://digitalis.uc.pt/pt-pt/termos.

Conforme exposto nos referidos Termos e Condições de Uso, o descarregamento de títulos de acesso restrito requer uma licença válida de autorização devendo o utilizador aceder ao(s) documento(s) a partir de um endereço de IP da instituição detentora da supramencionada licença.

Ao utilizador é apenas permitido o descarregamento para uso pessoal, pelo que o emprego do(s) título(s) descarregado(s) para outro fim, designadamente comercial, carece de autorização do respetivo autor ou editor da obra.

Na medida em que todas as obras da UC Digitalis se encontram protegidas pelo Código do Direito de Autor e Direitos Conexos e demais legislação aplicável, toda a cópia, parcial ou total, deste documento, nos casos em que é legalmente admitida, deverá conter ou fazer-se acompanhar por este aviso.

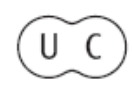


REVISTA DE HISTORIA DAS IDEIAS IO
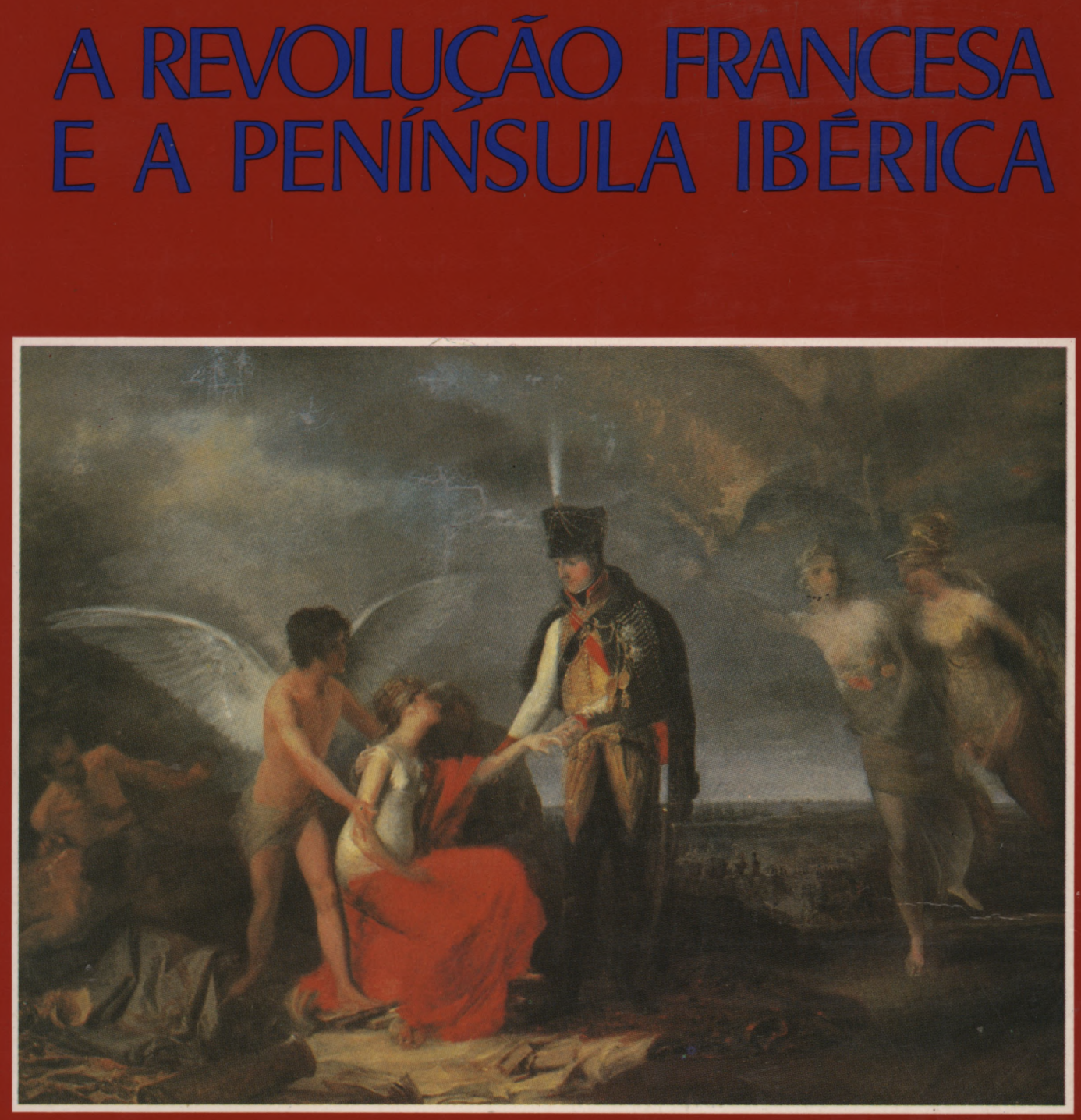

INSTITUTO DE HISTÖRIA E TEORIA DAS IDEIAS FACULDADE DE LETRAS 
ISILDA BRAGA DA COSTA

JOSE PAULO MOURA

SALVADOR MAGALHAES MOTA*

\section{A COMEMORAÇÃO DO CENTENARIO DA REVOLUÇÃO FRANCESA NA IMPRENSA DIÁRIA PORTUENSE}

O trabalho apresentado insere-se numa série já relativamente longa de estudos que a Faculdade de Letras do Porto tem desenvolvido ao longo dos últimos anos sobre a Revolução Francesa, principiando com os antigos Seminários de História Moderna e tendo tido continuidade nos actuais Seminários sobre as Invasões Francesas do curso de Mestrado em História Moderna, que os autores frequentam na sua fase terminal.

Pretende-se, essencialmente, verificar, em primeiro lugar, quais as comemorações que o centenário da Revolução Francesa suscitou no Porto e, em segundo lugar, de que modo os órgãos de informação diária representam a própria Revolução. Para tanto, e após o levantamento efectuado na imprensa quotidiana portuense de 1889 , elaborémos uma análise sucinta de cada um dos espécimes, buscando então a construção de modelos relativamente ao posicionamento ideológico desses jornais face à Revolução Francesa.

Evidentemente que se nos põe um problema, comum a todos os que trabalham com a imprensa, que é o de conhecer o grau de penetração dos jornais na vivência diária do povo português de 1889. Os dados sobre alfabetização são poucos e não estão tratados, e os dados relativos a tiragens são, na maioria dos casos, desconhecidos. Ignoramos também os esquemas de distribuição montados, ou seja, o grau de penetração no espaço nacional dos jornais consultados. Parece-nos, todavia, que os estudos deste tipo são importantes, enquanto indicadores de correntes de opinião e porque, para utilizar uma explicação lapalissiana, se os jornais existem, ainda que efemeramente, alguém tem de os

\footnotetext{
* Faculdade de Letras da Universidade do Porto (Mestrandos).
} 


\section{Revista de História das Ideias}

ler. De salientar, apenas, que nenhum dos quotidianos que em 1889 se publicavam no Porto tinha uma vocação local, antes, no mínimo, regional; e todos eles com aspirações a terem importância nacional.

Em 1889, o Porto era uma cidade essencialmente burguesa. A massa dos comerciantes, ligados ao tráfico dos produtos agrícolas, transformados ou em bruto, constituía a principal força motriz da vida económica portuense. Alguns dentre eles tinham investido na industrialização, ainda incipiente, originando uma classe operária pouco homogénea, constantemente em busca das soluções para o problema de uma distribuição mais justa da riqueza.

A segunda vertente social da cidade é constituída pela forte componente administrativa, a nível público, militar e eclesiástico. Sede de bispado, de um Tribunal da Relação e de região militar, o Porto adquiria assim, conjuntamente com o seu lado económico de centro aglutinador do Norte do país, um considerável peso político nacional, amplamente demonstrado pela importância histórica que alguns dos movimentos aqui iniciados vieram a ter. Uma massa de profissionais liberais, advogados e médicos, bem como de professores (a cidade possuía estabelecimentos de ensino secundário e politécnico), assumia funções de relevo na vida local, constituindo a mais importante fonte, conjuntamente com o clero, de recrutamento de colaboradores para a imprensa. Uma tentativa, ainda que fruste, de caracterização social do Porto de 1889 não pode esquecer a importância dos estrangeiros, sobretudo ingleses, nalguns casos estabelecidos na cidade há várias gerações, e influentes no sector económico onde se tinham instalado inicialmente, inserindo-se nos restantes sectores de actividade existentes na urbe. Relevantes cinda os proprietários rurais aqui estabelecidos, cuja área de influência se estendia do Minho ao Douro, completados pela série de pequenos comerciantes, de artesãos e de trabalhadores indiferenciados, que diversificavam a sociedade citadina, conferindo- lhe um carácter verdadeiramente vivo, no qual o pulsar permanente das tensões sociais horizontais e verticais dava o tom da sua vivência quotidiana, perfeitamente reflectidas no tecido urbano, dividido em áreas de influência, segundo o estrato sócio-económico.

A imprensa é o espelho das tensões de uma sociedade, desde que livre. Nela se reflectem as várias posições, ligeiramente discordantes ou antagónicas, que fazem da cidade um organismo 
vivo - organismo esse que, no Porto de 1889 , está ainda intimamente ligado à outra entidade civilizacional, geralmente em oposição, que é o campo. Campo e cidade interpenetram-se neste aglomerado em constante crescimento, fruto de um desenvolvimento económico, no plano comercial e industrial, em que muitos dos modos de pensar e de sentir são ainda profundamente rurais.

Melhor do que qualquer outro indicador, a imprensa vai reflectir essas contradições, e essas sínteses, que dão um carácter único e individualizado a cada cidade. $\mathrm{E}$, dentre os vários tipos de imprensa, a quotidiana, que pretende informar os seus leitores àcerca do que se passa no dia a dia de uma urbe, espelha ainda mais fielmente todas essas contradições, polémicas, sínteses ccasionais e definitivas que constituem o quotidiano de todos nós em qualquer época.

Numa altura em que a ilusão da regeneração nacional, no àmbito da monarquia constitucional, está, para muitos, morta, embora outros acreditem piamente no sistema, e alguns ainda pensem ser uma questão de reforma, não admira que proliferem os veículos de opinião, afectos a tais tendências. Concordantes em determinados pontos e divergentes noutros, todos, porém, acreditam possuir a chave para a felicidade e progresso humanos. Assim, uma cidade que não iria muito além dos 80000 habitantes, dos quais uma percentagem não determinada, mas relativamente escassa, segundo todos os indicadores, seria alfabetizada, sustentava, em 1889, pelo menos 16 jornais diários.

Dentre estes, muitos eram fruto de empenhamentos pessoais, quer em dedicação efectiva, quer a nível financeiro, de um grupo, por vezes muito pequeno, de pessoas, que pretendiam, deste modo, dar voz à sua mundividência e apregoar publicamente a solução, de que se julgavam portadores, para a crise nacional, arrecadando os respectivos dividendos políticos. De salientar que não são hoje conhecidas as fontes de subvenção destes periódicos, bem como as listas de assinantes.

Dos dezasseis diários que, ao longo de todo o ano ou somente durante parte dele, se publicavam em 1889, um não consta da colecção da Biblioteca Pública Municipal do Porto -A Tribuna -, impossibilitando-nos, por conseguinte, a sua consulta. Outros, porém, apresentam as colecções truncadas, nalguns casos acentuadamente, cuja busca e consulta teria de ficar para a fase final da pesquisa. Mesmo assim, parece-nos que o espólio recolhido é bastante significativo e importante para merecer um estudo.

Todos os jornais em estudo são de cariz essencialmente informativo, à excepção d'A Palavra, de índole confessional e 
ligado à hierarquia católica, veiculando, consequentemente, muito mais uma opinião sobre os principais factos da vida política nacional e internacional do que buscando informar os seus leitores àcerca dos pequenos casos do quotidiano. Em contrapartida, os restantes 14 dedicam uma atenção especial à vida citadina, variando a sua atenção de jornal para jornal, e onde os casos de polícia, os exames ou os problemas municipais ocupam, geralmente, lugar importante. Para além deste acervo noticioso, nota-se que os grandes temas da política nacional e internacional são sempre colocados em destaque, particularmente os relacionados com o poder político e os que afectavam, positiva cu negativamente, o mundo dos negócios.

Quanto ao que respeita à sua ligação com o poder, eles podem ser agrupados basicamente em duas facções: a primeira constituída pelos jornais que estão ligados aos partidos com alternância na direcção política do país - regeneradores e progressistas - e a segunda, formada pelos jornais que advogam uma alteração do sistema político-constitucional português, passando, qualquer que seja a forma que assuma, pela proclamação da República.

Não pretendemos com isto defender que estes grupos sejam homogéneos nas suas posições. As diferenças de posição entre regeneradores e progressistas, ou mesmo dentro de cada um destes subgrupos, são notórias, e nem todas as faç̧ões republicanas têm a mesma atitude face aos problemas nacionais. Recorde-se que esta divisão metodológica deverá ser articulada com o que atrás foi dito a respeito das diversas tendências. Todavia, os elementos que sobressaem desta análise relativamente à posição dos vários órgãos de informação face ao sistema político nacional, revelam que existe uma coerência interna dentro destes grupos, visível, por exemplo, no modo como representam a Revolução Francesa.

Teríamos, assim, no grupo dos jornais directamente implicados no jogo do poder, do lado progressista, que, em 1889, constituía governo, assumindo, no quadro político rotativista da Regeneração, a posição mais liberal: A Actualidade, O Comércio Português, o Dez de Março, e o Jornal da Manhã. Na oposição, ligada ao partido regenerador, tradicionalmente mais conservador, mencionaríamos $A$ Luta, o Jornal do Porto e o Jornal de Notícias. O Diário do Porto teve uma efémera aparição como órgão da esquerda dinástica nortenha, e $O$ Comércio do Porto e $O$ Primeiro de Janeiro mantêm uma posição ambígua, sem alinhamento partidário nítido, mas ligados ao poder. Defendem posições em geral conservadoras, o que não impede, no entanto, Rodrigues de Freitas de colaborar com regularıdade n'O Comér- 


\section{Centenário na Imprensa Diária Portuense}

cio do Porto. Pensamos que a capacidade de adaptação destes periódicos à situação política lhes terá assegurado a sua perdurabilidade, ou seja, a sua publicação até aos nossos dias. Com efeito, não se definindo claramente a favor ou contra o sistema político, não podem ser nunca implicados nos inêxitos deste, ou nas tentativas subversivas, revestindo-se de uma capa de independência, sob a qual se escudam os leitores que se supõem críticos em relação a tudo o que se passa à sua volta. Asseguram, assim, um público fiel, através do seu carácter na aparência exclusivamente informativo e sem alinhamento partidário.

Dentre os jornais ligados ao contra-poder, defendendo posições republicanas, teríamos o Diário do Comércio, A Democracia e $O$ Radical, também com tendências variadas, oscilando entre as preocupações marcadamente comerciais do primeiro e o radicalismo do último, unidos, porém, nas suas reclamações pela reforma total do sistema político-constitucional.

Deve-se desde já fazer notar que, relativamente às comemorações do centenário da Revolução Francesa, nenhum dos jornais se preocupa demasiado com elas, à excepção d'A Palavra, como veremos. O quadro que obtivemos das várias manifestações comemorativas foi respigado na leitura dos vários periódicos, particularmente nos republicanos, que se completam uns aos outros.

Temos assim que o grosso das notícias se concentra à volta do dia 5 de Maio e de 14 de Julho, os dois marcos da Revolução predominantemente comemorados em Portugal. A abertura dos Estados Gerais relevava o princípio constitucional e a tomada da Bastilha o da liberdade dos povos, capazes de, por suas próprias mãos, abaterem a tirania.

No dia 5 de Maio de 1889, as comemorações estiveram circunscritas à colónia francesa, que se reuniu no consulado para uma sessão de cumprimentos ao vice-cônsul, Fabri, expedindo, em seguida, um telegrama de congratulação ao Presidente da República Francesa, Sadi Carnot.

Só em 14 de Julho é que a cidade comemorou efectivamente o centenário da Revolução Francesa, através de uma série de manifestações, com origem em três pólos: a colónia francesa, os clubes republicanos e as associações operárias da cidade.

Nesse dia, a colónia francesa portuense reuniu-se num banquete no Palácio de Cristal, sob a presidência do vice-cônsul Fabri, num total de 27 convivas, que, após os brindes, enviaram novamente um telegrama a Carnot, seguindo-se uma récita no Teatro Chalet, onde foi representada a revista Pim-Pam-Pum, 


\section{Revista de História das Ideias}

que incluía no quadro final uma poesia do actor Dinis, recitada pelo próprio, intitulada "Viva a França». Esta récita, aparentemente, circunscreveu-se aos elementos da comunidade. De tudo ressalta o carácter exclusivista desta comemoração, ligada que esteve aos franceses residentes no Porto, essencialmente comerciantes e técnicos, não havendo notícia de qualquer português presente.

Os três clubes republicanos da cidade tiveram uma actuação bastante mais activa no que se refere à efeméride. Tratava-se de celebrar o princípio da capacidade dos povos de escolherem o melhor governo, aniquilando a tirania, consubstanciado na tomada da Bastilha. O «Clube Eleitoral Democrático Portuense» publicou um número único comemorativo, intitulado 14 de Julho, impresso a azul e vermelho, e do qual, infelizmente, não nos foi possível encontrar qualquer exemplar. Sabemos apenas que seria objecto de alguma procura, segundo informa a imprensa republicana, nomeadamente em Lisboa, e que inseria um artigo de Emídio de Oliveira, bastante celebrado pelo correspondente na capital d'A Democracia. Para além desta publicação, o clube organizou uma sessão solene, onde vários oradores teriam discursado sobre a importância da data comemorada. Não possuímos mais informações àcerca das iniciativas deste clube. A explicação pode residir no facto de se tratar de um clube ainda em formação $\left(^{1}\right)$, o que poderia levar a uma certa desconfiança da parte dos dirigentes dos dois centros republicanos já em actividade.

O «Clube Republicano Federal Guilherme Braga» $\left({ }^{2}\right)$ organizou igualmente uma sessão solene, presidida pelo «cidadão» Freitas, e na qual discursaram o Dr. Aureliano Cirne, director d'A Democracia, Ferreira Lisboa, administrador d'O Radical e Teixeira de Brito. Após os vivas levantados à França e ao partido republicano, dispersou-se a assembleia. $O$ discurso de Teixeira de Brito, intitulado «A Bastilha», foi posteriormente publicado n'A Democracia, nos dias $17,18,22$ e 23 de Julho $\left({ }^{3}\right)$. Nele se estabelecia uma oposição entre o mundo pré e pós-1789, que se prolongava na oposição monarquia/república, tirania e despotismo contra razão, luz, liberdade e justiça. Considerava

(1) Um anúncio publicado n'O Radical, ano II, n. 82 , de 7 de Julho de 1889. convoca uma reunião para a formação do "Clube Eleitoral Democrático Portuense», a realizar na sede do «Clube de Propaganda Democrática do Norte».

(2) Ao tempo situado na Rua da Boavista, 1488, na zona de Serralves, Lordelo do Ouro.

(3) Cf. A Democracia, ano V, n. ${ }^{\text {ss }} 278,279,282$ e 283. 
ainda o orador que todos os coevos eram filhos da revolução, dividindo-os, maniqueisticamente, em bons e maus, em referência aos ideais revolucionários, ou seja, em republicanos e monárquicos. A Bastilha era o símbolo dos crimes da execranda instituição monárquica, a qual, por sua vez, era fruto da ingenuidade dos povcs, ao conferirem o poder a um homem, que de «chefe» passava a «senhor», e se aliava, para maior eficácia despótica, ao Altar, profundamente implicado nos crimes do Trono, e cujas «trevas» urgia substituir pela «luz» do positivismo. O Trabalho era a síntese do princípio místico-religiosc, o único ideal a ter em conta. À devassidão da monarquia contrapunha-se a frugalidade e a hombridade republicanas, corporizando o partido republicano, numa perspectiva universalista, as aspirações ae justiça e de liberdade. Advogava, por fim, a implantação na sociedade humana dos «generosos» princípios de 1789 - cristalizados na trilogia Liberdade, Igualdade e Fraternidade.

Após o termo desta sessão solene, outra começava de imediato no «Clube de Propaganda Democrática do Norte» ( ${ }^{4}$ ), especialmente engalanado para o efeito com bandeiras tricolores, plantas e cem lâmpadas eléctricas a iluminar a rua, simbolizando a relação que se pretendia estabelecer entre luz eléctrica, progresso, democracia e república.

Presidida pelo «cidadão» Carlos Richter (que, em 1911, viria a ser eleito deputado por Vila Real à Assembleia Constituinte), consistiu o acto na leitura e aprovação de uma mensagem a enviar ao cônsul francês, na leitura de uma carta de adesão do chefe do partido republicano, Dr. Alves da Veiga e de diversos telegramas de vários clubes do Norte do país, não identificados, precedendo os discursos. O primeiro foi pronunciado por Eugénio da Silveira, redactor do Século, que, para o efeito, veio expressamente de Lisboa, tendo-se concentrado no significado da efeméride comemorada. Seguiu-se-lhe o Dr. Aureliano Cirne, d'A Democracia, que considerou a Revolução Francesa sob dois aspectos: o político e o económico. O primeiro considerou-o ele resolvido, não especificando se se referia à implantação da jepública em França ou ao constitucionalismo português. $\mathrm{Na}$ explanação dos seus considerandos sobre o aspecto económico, defendeu que as classes operárias portuenses necessitavam de uma maior organização e de uma melhor orientação, advogando a constituição de caixas económicas. Estas deveriam ultrapassar o mero objectivo mutualista, dado que lhes conferia a dupla atribuição de depósito de pequenas poupanças para assegurar o sustento da velhice operária e de constituição de um fundo de

(4) Na Rua Formosa, 280. 
maneio para a manutenção de greves, consideradas «o único recurso de que pode lançar mão o proletariado».

Outros oradores intervieram a seguir, entre os quais Felizardo Lima, director político d'O Radical. Por fim, foi nomeada a comissão encarregada de entregar a Fabri, o vice-cônsul francês, a mensagem congratulatória redigida, em estilo empolado, por Sampaio Bruno, e que o jornal publicou na segunda página $\left(^{5}\right)$. Dela faziam parte Joaquim Bessa de Carvalho, Manuel Guedes de Ferreira Ramos, José Maria Durão, António Augusto Borges da Mota, Eugénio da Silveira, José de Sousa Melo, Manuel Joaquim Tavares da Rocha, António José de Almeida, Carlos Richter, Alberto A. Pereira, António Pereira de Sousa e António Coutinho Russo.

A mensagem de Sampaio Bruno demonstra bem o francesismos dos republicanos portuenses, considerando a França como a luz que guiou os povos no caminho da democracia e salientando os princípios consignados na Declaração dos Direitos do Homem $e$ do Cidadão como os fundamentais para o progresso da humanidade. A primeira ideia que ressalta da leitura do texto é a de haver Portugal seguido de perto o caminho da França - porventura aludindo à Revolução de 1820 - e ter ficado a dever-lhe essa luz, como outras ao longo da sua história, desde a fundação da nacionalidade à restauração de 1640 . Curiosamente, nenhuma referência é feita às invasões francesas. A profunda ligação entre os dois países é assim exaltada, numa demonstração de fraternidade universal, de resto também sequela da Revolução. Esta visão da França, que se nos assemelha a uma espécie de єstrela de Belém da liberdade, conduz-nos à segunda ideia-força do texto, que é a de uma mística republicana, ligada à Declaração dos Direitos, comparada ao Evangelho, a reflectir uma religiosidade natural, quiçá de raiz voltairiana. $\mathrm{E}$ o texto termina com o significativo grito de "Viva a França». A música d'A Marselhesa acompanhou a sessão, tal como vai suceder na comemoração do Salão Euterpe $\left(^{(\boldsymbol{)})}\right.$.

Aqui, com efeito, organizaram as agremiações operárias da cidade (nenhum jornal adianta pormenores) um sarau cultural e recreativo, a assinalar o primeiro centenário da Revolução Francesa. De salientar o facto de este sarau se destinar à recolha de fundos para o envio de um representante operário ao Congresso Socialista de Paris. Os discursos políticos alternam com a poesia comemorativa e a música d'A Marselhesa, numa aparente demonstração do valor didáctico das artes na formação política

(5) Cf. A Democracia, ano V, n. $.^{\circ} 276,15$ de Julho de 1889, p. 2.

(6) Sito na Rua das Portas do Sol. 


\section{Centenário na Imprensa Diária Portuense}

da classe operária. Uma observação, ainda que rápida, ao programa da sessão: nota-se que os discursos procuram acentuar a acuidade dos problemas da classe operária face à industrialização e, sobretudo, relativamente à posse dos meios de produção, salientando as semelhanças entre o povo francês antes de 1789, escravizado pelo despotismo, e o operariado coevo, escravizado pelo capitalismo. Interessante ainda o qualificativo aplicado a dois dos oradores presentes: «inteligente». $\mathrm{Na}$ verdade, n'A Democracia como noutros jornais, só vimos este adjectivo aplicado a crianças estudantes, de quem se pretendia exaltar a capacidade futura, lisongeando os pais. No caso presente, parece-nos ser uma tentativa paternalista do partido republicano em relação a uma classe operária em vias de consciencialização e cujo controle, em parte, lhe escapava.

O único texto que possuímos desta sessão é o de uma poesia de Roberto dos Santos, um operário republicano colaborador habitual d'A Democracia, intitulada «14 de Julho» e dedicada aos republicanos portuenses, inserida na segunda página do mesmo jornal do dia $15\left(^{7}\right)$.

Dividiu-a o autor em duas partes: a primeira com vinte e seis versos emparelhados e a segunda com seis quadras. $\mathrm{Na}$ primeira parte é feita uma saudação à França, e ao povo francês, particularmente aos habitantes de Paris, enquanto baluartes da liberdade e focos da nova luz que iluminava a humanidade, sendo de novo a república apontada como o repositório da ciência, do bem, da justiça e do progresso. A segunda parte é um apelo aos democratas para que sigam o exemplo francês.

Referimos as horas das sessões que conhecemos, por nos parecerem significativas, dos Clubes «Guilherme Braga» e de «Propaganda Democrática do Norte», bem como do Salão Euterpe: a primeira realizou-se às $15,30 \mathrm{~h}$, a segunda às $19,00 \mathrm{~h}$ e a última às $20,30 \mathrm{~h}$. Sem dúvida procurava-se evitar uma dispersão do público - os oradores de uma colaboravam nas outras e parece legítimo pensar que parte do público poderia igualmente estar presente nas diversas sessões, até por se tratar de um domingo.

Que outras comemorações, de âmbito particular, tiveram lugar na cidade, sabemo-lo por notícias esparsas pelos vários jornais, que se referem genericamente a iluminações várias. A única referência explícita, porém, encontramo-la n'O Dez de Março, que noticia, em estilo publicitário, haver o proprietário de um bazar denominado «14 de Julho», Almeida e Silva, tê-lo mantido iluminado no dia da comemoração.

(7) Cf. A Democracia, ano e n..$^{\circ}$ cit. 


\section{Revista de História das Ideias}

Face à data do 14 de Julho os jornais assumem posições naturalmente diferentes. Aqueles que acima classificámos como estando em estreita relação com o poder limitam-se a anunciar ou a noticiar a posteriori, quando muito, as diversas comemorações, de uma forma parcelar, dando a entender que nada de especial se tinha passado. Deve ser feita, no entanto, uma excepção relativa aos actos comemorativos organizados pela comunidade francesa que, por serem restritos aos nacionais, foram considerados como inócuos e noticiados na maioria dos quotidianos. De um modo geral, estes não prestaram nenhuma atenção particular às comemorações. Assim aconteceu também com um periódico do grupo republicano, o Diário do Comércio. Esta posição parece-nos, decorrente da sua representação da Revolução Francesa, como veremos. A Democracia, pelo contrário, consagra página e meia às comemorações, para além de um amplo espaço concedido nos dias seguintes. De referir, ainda, gue 14 de Julho tinha sido a data em princípio apontada para a passagem d'O Radical a diário. Contudo, devido ao que nos parece uma enorme desorganização interna, inicia essa periodicidade um mês antes.

Como já se referiu, a posição dos diários portuenses, relativamente às comemorações locais do centenário da Revolução Francesa, decorre da representação específica que cada um constrói da própria Revolução. Em nenhum dos jornais citados ela aparece como factor de constante menção. Saliente-se, porém, nas referências que lhe são feitas, o posicionamento diverso de cada periódico, decorrente da sua linha ideológica.

Assim, no grupo dos jornais relacionados com o poder sublinhe-se, em primeiro lugar, que as referências à Revolução Francesa são feitas unicamente sob um tríplice pretexto: os editoriais de abertura do ano, as principais datas comemoradas em Portugal e as celebrações efectuadas em França, em particular as relacionadas com a Exposição Universal de Paris. Com efeito, esta assumia uma importância bastante grande numa cidade onde o sector económico era bastante activo, sendo, por isso, numerosas as referências a expositores e visitantes portuenses. Muitas delas são pretextadas pelos comentários à própria Exposição, através da qual se pretendia celebrar o génio francês e, concomitantemente, a República.

De um modo geral, estes periódicos assumem posições semelhantes em relação à Revolução Francesa, independentemente do seu alinhamento partidário. Para eles, ela foi, em primeiro lugar, um evento francês que, pelo carácter universalista deste povo, se espalhou ao resto da humanidade, convertendo-se na grande revolução social e política, triunfo da liberdade, 
criadora do sistema constitucional monárquico, que assegurava a tranquilidade e o bom governo das nações. E notória, nestes quotidianos, a preocupação de relembrar aos seus leitores que 1789 não deve ser confundido com a barbárie assassina de 1793 . Muitos destes jornais, inclusive dentre os que estão ligados ao partido progressista, criticam o governo por não ter considerado oficial a representação portuguesa na Exposição Universal de Paris. Advertem, porém, que a comemoração deste importante centenário não deve dar azo a manifestações subversivas minando o sistema político-constitucional instituído, razão pela qual se demarcam das celebrações portuenses, da iniciativa do partido republicano.

De salientar o facto de apenas um periódico, o Jornal da Manhã, dentre os quinze consultados, se referir às invasões francesas como consequência da revolução, mas sublinhando, em primeiro lugar, que resultaram de uma adulteração posterior dos próprios ideais revolucionários, e, em segundo lugar, que se devem entender como um movimento de generosidade, se bem que desastrada, de um povo desejoso de espalhar a sua boa nova pela humanidade. Terão ainda de ser compreendidas face aos prejuízos da ocupação pacífica inglesa, que se tinha anunciado como de libertação fraterna.

O Diário do Porto, órgão da esquerda dinástica, não lhe faz qualquer referência, o que se pode explicar pelo curto período de publicação deste quotidiano, que se estende tão só de 13 de Janeiro a 11 de Fevereiro de 1889.

Entre os periódicos que assumem uma posição contra o poder, aventando como alternativa a instauração da República, rão há uma convergência na forma de representar a Revolução Francesa. Assim, A Democracia, que se assume sobretudo como órgão republicano, admite no seu seio tendências diversas, desde as que advogam uma relação mais moderada com o poder, às mais extremistas, que invocam a necessidade de uma insurreição para que a monarquia corrupta, responsável pelos males nacionais seja derrubada, bem como os seus aliados, nomeadamente a Igreja. Nesta tendência se insere, por exemplo, um artigo sob a epígrafe de «E os canhões não troaram», publicado em 16 de Julho, no qual se comenta o facto de D. Luís ter ido ouvir missa no domingo anterior, dia 14 . Segundo o articulista, tratar-se-ia de uma acção de graças pela falta de sentido patriótico do povo português, que lhe permitia actos bem mais nefandos do que os que, em França, haviam conduzido Luís XVI ao cadafalso.

O Diário do Comércio, ligado às actividades económicas, particularmente ao trato dos vinhos, assumia posições em geral mais moderadas. Para este quotidiano, a Revolução Francesa 
fora um acontecimento, sem dúvida importante, mas cuja celebração devia ter um sentido eminentemente histórico, por haver contribuído para a implantação dos princípios imortais da Liberdade, da Igualdade e da Fraternidade. E por aqui fica a atenção dada às comemorações.

Como o seu próprio nome indica, $O$ Radical tomava posições mais duras face à monarquia, advogando soluções violentas para a resolução dos problemas sociais. Sem uma periodicidade concreta $\left({ }^{8}\right)$, o principal artigo de análise à Revolução Francesa é uma transcrição d'O Alenquerense, por Horácio Ferraria, inserto em 13 de Maio, ainda na fase de publicação semanal. Considera-a ainda não terminada, pois que falta aplicar na prática os justos princípios enunciados em 1789. A revolução política na altura operada deverá juntar-se a revolução social, augurada para o século $\mathrm{XX}$, em que os trabalhadores assumiriam a direcção dos seus destinos. De notar que, pela primeira vez, a Revolução Francesa é apontada como um fenómeno marcadamente burguês.

De um modo geral, para este grupo de jornais, o evento de 89 é considerado como um marco fundamental na caminhada dos povos para a democracia e para o progresso, que só terminaria quando a República implantasse os princípios da Declaração dos Direitos do Homem e do Cidadão. Era esse o novo Evangelho, para os que consideravam a religiosidade, sem confessionário nem celibato, logo protestante, como a "democracia mística».

Posição radicalmente oposta assume A Palavra. Jornal de vincado acento confessional, ligado à hierarquia católica, e de cariz ideológico legitimista, justifica por si só mais detido tratamento $\left({ }^{9}\right)$. Com efeito, se não lhe passa despercebida a comemoração do centenário da Revolução Francesa, recusa dar-lhe demasiada atenção. Não faz, por exemplo, qualquer referência às comemorações portuenses, embora não deixe de chamar a atenção a todos os contemporâneos para os perigos que ela representava.

Ao longo de todo o ano apenas seis artigos de fundo são directamente dedicados à efeméride e, desses, três são traduções da Correspondência de Roma. Para os redactores d'A Palavra, a Revolução Francesa era uma doença social, um facto hediondo e revoltante do passado humano, cujas consequências nefastas

(8) Pretendendo, a partir de Junho de 1889. passar de semanário a diário, limita-se a alguns números esparsos, extinguindo-se a colecção da B.P.M.P., abruptamente, em 7 de Julho.

(9) Este periódico mereceu exaustivo tratamento, no respeitante à sua concepção da sociedade e aos deveres do Estado, da parte do Prof. Doutor João de Almeida Policarpo. 
pareciam estar em vias de ser ultrapassadas. Não importaria, pois, ser relembrada, em demasia, aos leitores sensíveis, que por outro lado, a deveriam ter sempre em mente, em virtude das sequelas horríveis, a reflectirem-se ainda na sociedade coeva.

A Revolução Francesa é apontada como sinónimo de anarquia, de sangue, de dor, de violência, por oposição à celebração, ric ano anterior, do Jubileu de Leão XII, ou seja, à Igreja, apresentada como símbolo da ordem temporal, passível de realizar a paz, a concórdia, o progresso e o bem-estar humanos na terra. Expressão satânica e portadora de males profundos, bem como inimiga do rei, investido por Deus de poder absoluto, por intermédio da Igreja, ela surge como verdadeira ameaça à paz e ao progresso humanos. Inverte-se, deste modo, n'A Palavra, a visão da Revolução Francesa relativamente a todos os outros órgãos de informação periódica já mencionados.

A análise intentada ficaria incompleta se não fizéssemos uma leitura, ao de leve que fosse, dos semanários e revistas portuenses ccevos. Na verdade, parecia-nos que esta imprensa de periodicidade mais espaçada poderia fornecer-nos uma visão mais detida da Revolução Francesa.

A sondagem a que procedemos mostrou-nos que a Revista de Portugal, mensário que se começou a publicar em 1 de Julho ae 1889, dirigido por Eça de Queirós, constituiria um bom aferidor. Com efeito, o grupo dos seus colaboradores incluía nomes de primeira grandeza do panorama político, social e literário nacional, muitos dos quais ligados às ideias republicanas e ao sccialismo utópico, como Antero de Quental, Anselmo de Andrade, António Cândido, Alberto Sampaio, Conde de Casal Ribeiro, Conde de Ficalho, Fialho de Almeida, Guerra Junqueiro, Maria Amália Vaz de Carvalho, Oliveira Martins, Pinheiro Chagas, Ramalho Ortigão, Rodrigues de Freitas e Teófilo Braga, entre outros.

Expectativa algo frustrada, pois apenas um artigo do seu primeiro número se refere à comemoração da Revolução Francesa, sob o título de «Crónica Política Internacional». Assina-o P. de Oliveira. Trata-se de Joaquim Pedro de Oliveira Martins, que assim subscrevia, julgamos, os artigos de crónica política.

A pretexto da Exposição Universal de Paris, o autor começa por analisar a efeméride revolucionária, considerando que a panóplia de banquetes, fogos de artifício, discursos e revistas escondia do público o verdadeiro motivo do certame, que era o de celebrar, de forma encomiástica, as realizações do génio francês, um século após 1789 . 
$\mathrm{Na}$ segunda parte, $\mathrm{P}$. de Oliveira detém-se nos princípios definidores da Revolução - a Liberdade, a Igualdade e a Fraternidade - os quais, na sua opinião, deveriam ter substituído «as três virtudes cardeais fósseis da Fé, Esperança e Caridade», comentando, a propósito, o grau da sua implantação no quotidiano das populações, cem anos depois de terem sido proclamados. A conclusão negativa a que chega, leva-o a afirmar que a sociedade dos finais do século XIX, «utilitária, experimental, naturalista e egoísta», mostrava-se insensível a esses princípios que, um século antes, haviam desencadeado furor. $O$ único resultado prático da Revolução Francesa acabava por ser, para o articulista, a instauração do reino da ciência, de que a verdadeira apoteose e espectacular símbolo era a Torre Eiffel.

Em vários dos jornais consultados surgem ainda algumas referências, nunca muito extensas, a celebrações noutros pontos do país, nomeadamente em Lisboa, Coimbra, Braga, Viana do Castelo e Vila Real, bem como a outros eventos comemorativos efectuados no estrangeiro, com especial destaque, naturalmente, para a França. Não os consideramos, porém, na presente panorâmica, devido à escassez das referências e à compreensível delimitação deste trabalho.

Por fim, parece-nos que as comemorações portuenses do centenário da Revolução Francesa devem ser encarados como um fenómeno circunscrito à comunidade francesa entre nós estabelecida, aos clubes republicanos e às agremiações operárias. Assim, os franceses celebravam-no enquanto facto relevante da sua história nacional e os republicanos e operários por motivos políticos. Por outro lado, os quotidianos afectos aos implicados nos jogos do poder demarcam-se claramente desses actos comemorativos, sem, contudo, negarem a importância da Revolução para a história da humanidade.

De qualquer modo, foi dada atenção à efeméride na cidade do Porto, constituindo motivo de reflexão mesmo para aqueles que historicamente a negavam ou a diminuíam e denegriam. Pode afirmar-se que, independentemente das diversas interpretações e posições provocadas, os princípios teóricos proclamados em 1789 eram, um século mais tarde, demasiado importantes, no plano das consequências desencadeadas, para serem esquecidos, sobretudo numa cidade em que a correlação de forças económicas e correntes ideológicas se mostrava assaz sensível aos problemas do controle dos meios de produção e do acesso ao poder político. 
Constituindo o presente trabalho uma primeira tentativa de um estudo mais vasto a realizar, limitámo-nos, por agora, a fornecer algumas tentativas de exemplificação relativas à temática em questão, e a apresentar as conclusões da pesquisa efectuada.

\author{
FONTES IMPRESSAS - 1889 \\ Lista dos jornais consultados \\ (Janeiro a Dezembro) \\ A Actualidade \\ O Comércio do Porto \\ O Comércio Português \\ A Democracia \\ O Dez de Março \\ Diário do Comércio \\ Diário do Porto \\ Jornal da Manhã \\ Jornal de Notícias \\ Jornal do Porto \\ A Luta \\ A Palavra \\ $O$ Primeiro de Janeiro \\ A Provincia \\ $O$ Radical \\ Revista de Portugal
}

